Revta brasil. Bot., São Paulo, V.24, n.3, p.349-357, set. 2001

\title{
Development and some histochemical aspects of foliar glandular trichomes of Stevia rebaudiana (Bert.) Bert. - Asteraceae
}

\author{
WALKYRIA ROSSI MONTEIRO ${ }^{1}$, MARÍLIA DE MORAES CASTRO $^{2,5}$, SOLANGE CRISTINA \\ MAZZONI-VIVEIROS $^{3}$, and PAUL GORDON MAHLBERG ${ }^{4}$
}

(received: February 14, 2001; accepted: June 20, 2001)

\begin{abstract}
Development and some histochemical aspects of foliar glandular trichomes of Stevia rebaudiana (Bert.) Bert. - Asteraceae). The ten-celled biseriate glandular trichome of Stevia rebaudiana (Bert.) Bert.-Asteraceae, found on both leaf surfaces, originates from a single protruding, protodermal cell undergoing an anticlinal division. A subsequent series of periclinal divisions, occurring in acropetal sequence, leads to the formation of the trichome, composed of five pairs of cells, one pair of basal cells, another of stalk cells and three pairs of secretory head cells. Developing, still two-celled glandular trichomes already occur on leaf primordia of the second pair (these primordia measuring, in some cases, ca. $0.30 \mathrm{~mm}$ in length), and most of the glandular trichomes are at the mature phase on very young, expanding leaves, for example on those of the sixth pair. The secretory material released by the head cells is stored in the trichome cavity (subcuticular space). Basic histochemical tests reveal that such material is lipophilic (mainly) and hydrophilic in nature.
\end{abstract}

RESUMO - (Desenvolvimento e alguns aspectos histoquímicos de tricomas glandulares decacelulares bisseriados de Stevia rebaudiana (Bert.) Bert.-Asteraceae). O tricoma glandular decacelular bisseriado de Stevia rebaudiana (Bert.) Bert.-Asteraceae, encontrado em ambas as superfícies da folha, origina-se a partir de uma célula protodérmica protuberante que sofre uma divisão anticlinal. Uma subseqüente série de divisões periclinais, ocorrendo em seqüência acrópeta, leva à formação do tricoma, composto por cinco pares de células: um par de células basais, um outro de células pedunculares e três pares de células secretoras da cabeça. Tricomas glandulares em desenvolvimento, ainda com duas células, já ocorrem em primórdios foliares do segundo par (estes primórdios medindo, em alguns casos, cerca de $0,30 \mathrm{~mm}$ em comprimento) e, em sua maioria, estão em fase madura em folhas muito jovens, ainda em expansão, como naquelas do sexto par. O material de secreção, liberado pelas células da cabeça, é armazenado na cavidade do tricoma (espaço subcuticular). Testes histoquímicos básicos revelam que, em sua natureza, tal material é lipofílico (principalmente) e hidrofílico.

Key words - Stevia rebaudiana, Asteraceae, glandular trichomes, ontogeny, histochemistry

\section{Introduction}

Stevia rebaudiana (Bert.) Bert. (Asteraceae) is native to Paraguay and neighboring Brazilian border (Monteiro 1982). It produces stevioside (a diterpenoid tetracyclic glycoside), a noncaloric sweetener considered to be 100-400 times as sweet as sucrose (Felippe 1977, Handro \& Ferreira 1989, Kinghorn \& Soejarto 1991). Nephrotoxicity is thought

1. Universidade de São Paulo, Instituto de Biociências, Departamento de Botânica, Caixa Postal 11461, 05422-970 São Paulo, SP, Brasil.

2. Universidade Estadual de Campinas, Instituto de Biologia, Departamento de Botânica, Caixa Postal 6109, 13083-970 Campinas, SP, Brasil.

3. Secretaria de Estado do Meio Ambiente, Instituto de Botânica, Seção de Anatomia e Morfologia, Caixa Postal 4005, 01061970 São Paulo, SP, Brasil.

4. Indiana University, Department of Biology, Bloomington, Indiana 47405, USA.

5. Corresponding author: mariliac@ unicamp.br to be caused by stevioside in studies on rats (Toskulkao et al. 1994, Melis 1995).

In experiments performed by Zaidan et al. (1980) on vegetative organs (including roots) and reproductive organs of $S$. rebaudiana plants, the stevioside was obtained from leaf (the most productive organ), stem and inflorescence.

Results from some morphological, structural, ultrastructural, histochemical, and even biochemical studies, carried out on glandular trichomes of many species of Asteraceae, aided in characterizing the trichome and its secretory material (Carlquist 1958, 1959a, Schnepf 1969, Vermeer \& Peterson 1979a, b, Karrfalt \& Kreitner 1980, Kelsey \& Shafizadeh 1980, Werker \& Fahn 1981, 1982, Ascensão \& Pais 1982, Ascensão \& Pais 1985, Cappelletti et al. 1986, Ascensão \& Pais 1987, Duke \& Paul 1993, Duke et al. 1994, Werker et al. 1994, Afolayan \& Meyer 1995, Corsi \& Nencioni 1995, Ferreira \& Janick 1995); only a few of the structural studies include ontogenetic aspects. Results from the observations on the 
glandular trichomes of Asteraceae have proved to be important contributions to some taxonomic and/ or phylogenetic questions (Carlquist 1959a, Narayana 1979, Maleci \& Marchi 1983, Kelsey 1984, Spring 1991, Hellwig 1992, Castro et al. 1997). In addition, the material produced by the glandular trichome is interpreted to function in ecological roles in many species (Levin 1973, Fahn 1979, Kelsey et al. 1984, Duffey 1986, Wagner 1991, Duke 1994).

The objectives of this report are to: 1) describe the development of the ten-celled biseriate glandular trichome, of abundant occurrence on leaves of $S$. rebaudiana, and 2) apply some routine histochemical techniques to this gland to obtain information on the chemical nature of its secretory product.

\section{Material and methods}

Plants were grown from seeds in a greenhouse of the Department of Biology, Indiana University, Bloomington, U.S.A. Seeds were supplied by the Instituto de Botânica, São Paulo City, SP, Brazil.

Plants were grown at about $25{ }^{\circ} \mathrm{C}$, under continuous long-day conditions ( $16 \mathrm{~h}$ photoperiods) to be maintained in vegetative state, since $S$. rebaudiana is a photoperiodic shortday flowering plant (Válio \& Rocha 1977).

Vegetative shoot apices and different regions of fully expanded young leaves were fixed in FAA (Lersten \& Curtis 1988) for 24 h, Lillie's buffered neutral formalin (Clark 1981a) for $65 \mathrm{~h}$, and formalin-ferrous sulphate reagent (Johansen 1940) for $48 \mathrm{~h}$. Before dehydration the samples fixed in Lillie's buffered neutral formalin and those fixed in formalinferrous sulphate reagent were washed for $2 \mathrm{~h}$ in 9 and 5 respectively, changes of deionized water. All samples were dehydrated through a tertiary butyl alcohol series, embedded in paraffin and then sectioned (Johansen 1940). Serial transections and longisections of shoot apices, and serial transections of samples taken from leaves, were cut at $5 \mu \mathrm{m}$ thickness on a rotary microtome.

Fresh, freehand transections of expanding, and fully expanded young leaves were also obtained for study.

Sections from samples fixed in FAA were stained with tannic acid-iron chloride, Safranin and Fast green (Schneider 1981) for regular histological observations.

Paraffin sections from samples fixed in formalin-ferrous sulphate reagent were only deparaffinized (Johansen 1940) in order to reveal the histochemical localization of phenolic substances.

Besides the treatment with the formalin-ferrous sulphate reagent, other histochemical procedures were performed to detect: insoluble carbohydrates in samples fixed in FAA by the periodic acid-Schiff's (PAS) test (Jensen 1962), the control being made by omission of treatment with periodic acid (Riding \& Gifford 1973); pectinaceous materials in samples fixed in Lillie's buffered neutral formalin by staining with Alcian blue 8GS (Clark 1981b); pectinaceous materials by staining freehand sections with Ruthenium red (Jensen 1962); lipids by staining freehand sections with Sudan black B (Jensen 1962).
Photomicrographs were taken with a Zeiss III photomicroscope.

\section{Results}

Developmental aspects - After enlarging and protruding above the leaf surface, a single protodermal cell (figure 1) undergoes an anticlinal, symmetric division, resulting in the trichome two-cell stage (figure 2). Both cells divide periclinally to form the four-cell stage (figure 3 ). This stage is followed by the six- (figures 4, 5), eight- (figure 6), and ten-cell (figure 7) stages, resulting from a periclinal division taking place in the upper cells of the four-, six-, and eight-cell trichomes, respectively. These cells do not appear to divide synchronously in the passage from one stage to another. The trichome of figure 4 has three cells in its right half and, still, two cells in the left half; that of figure 6 has already four cells in its left half, while the upper cell in the three-celled right half is still dividing.

After reaching the ten-cell stage, the trichome expands and differentiates. In face view, a mature trichome (figure 8) is composed of five pairs of cells: one pair of basal cells, another of stalk cells, and three pairs of secretory head cells. Figures 9 and 10 show the trichome in lateral view with the presence of translucent, vertically elongated areas interspersed in the walls of the head cells. In mature trichomes (figures 10,11), secretory materials are accumulated in the trichome cavity (subcuticular space), which possesses a surface sheath (secretory sheath). This sheath, lightly stained in figure 8 , is clearly visible in figures 10 and 11.

Glands are initiated very early in leaf development. The longisections shown by figures 12,13 and 14 are of a shoot apex in which the leaf primordia of the $1^{\text {st }}$ pair measures ca. $0.06 \mathrm{~mm}$ in length, and the young leaves of the $2^{\text {nd }}$ pair, ca. $0.30 \mathrm{~mm}$. In figure 14 two-celled glandular trichomes are already present on a leaf belonging to the $2^{\text {nd }}$ pair. In the $6^{\text {th }}$ pair of developing young leaves, the oldest one frequently seen in the sectioned shoot apices, most glandular trichomes are at the mature phase, and form, together with nonglandular trichomes, a dense covering on both leaf surfaces (figures 15, 16). On those leaves, however, it is still possible to find some glands at early developmental stages, as shown by figure 16 . Pointed by an arrow in this figure is a developing glandular trichome, which may be at the 


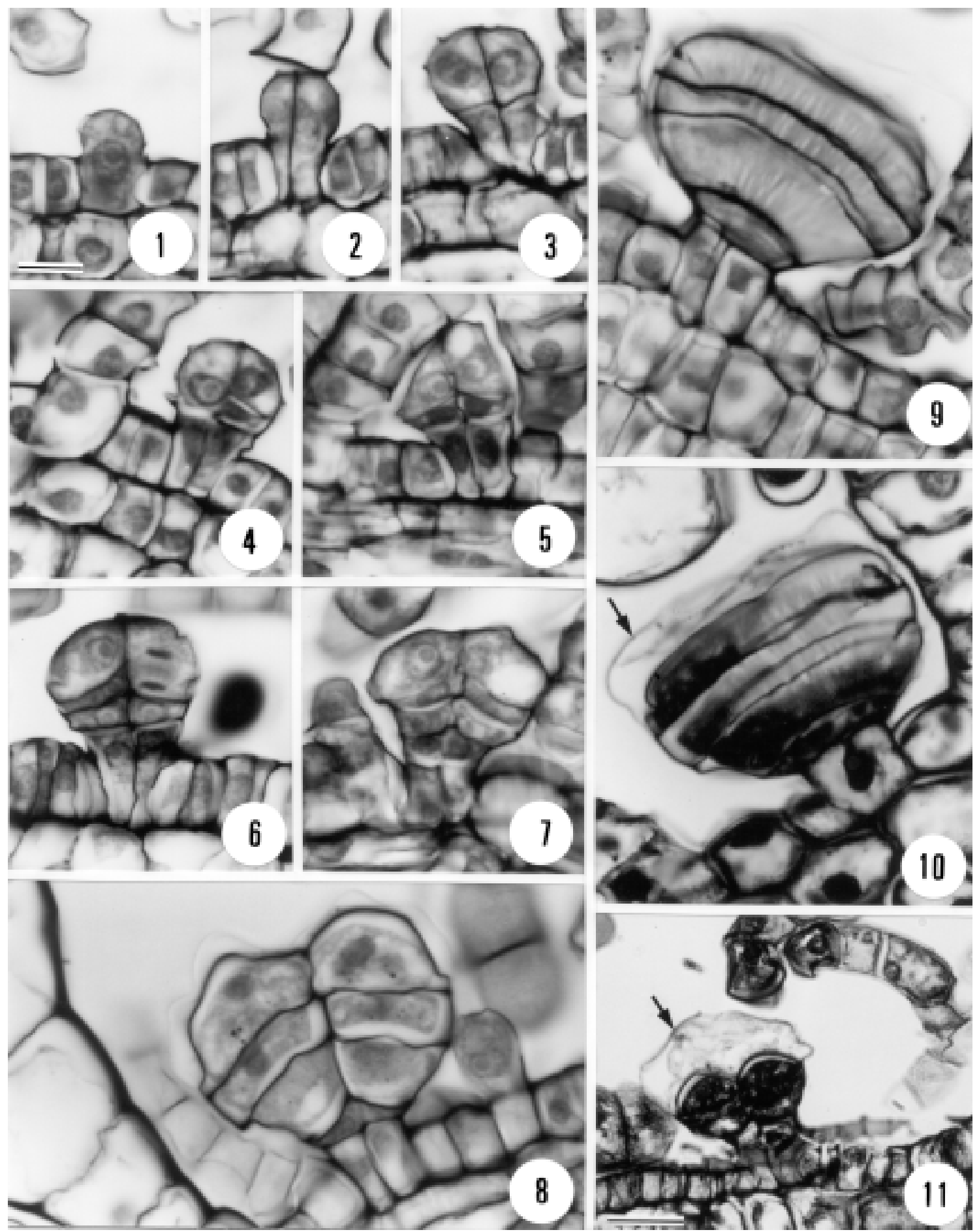

Figures 1-11. Stevia rebaudiana (Bert.) Bert. Developing and mature glandular trichomes, seen in longisections (1-7, 11) and transections (8-10) of shoot apices. 1-9. PAS test. 10, 11. Tannic acid-iron chloride, Safranin and Fast green. 1. Protruding protodermal cell. 2-7. Products of cell divisions: two-cell (2), four-cell (3), six-cell (4, 5), eight-cell (6) and ten-cell (7) stages. 8-11. Mature trichomes, in face view $(8,11)$ and lateral view $(9,10)$; arrows $(10,11)$ : secretory sheath. See text for description. Bar $=10 \mu \mathrm{m}(1-10)$ and $20 \mu \mathrm{m}(11)$. 

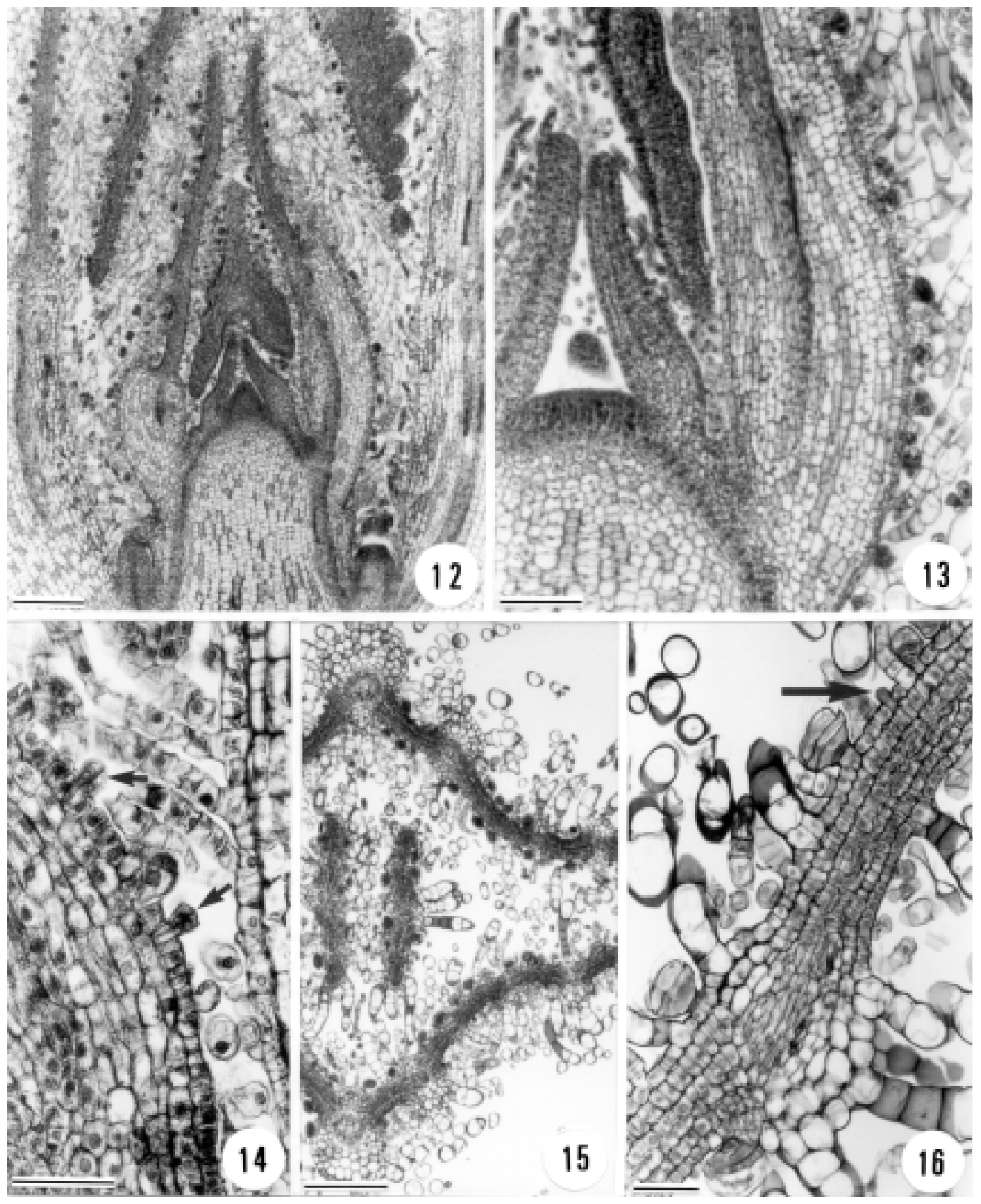

Figures 12-16. Stevia rebaudiana (Bert.) Bert. Developing and mature glandular trichomes on leaf primordia of different ages, seen in longisections $(12-14)$ and transections $(15,16)$ of shoot apices. 12-15. Tannic acid-iron chloride, Safranin and Fast green. 16. PAS test. 12-14. Three different sections of a shoot apex. 12. General view. 13. Details, in a median section: apical meristem, and portions of developing leaves of the $1^{\text {st }}$ (in paradermal plane), $2^{\text {nd }}, 3^{\text {rd }}$ (in paradermal plane) and $4^{\text {th }}$ pairs. 14. Details, in another section - developing leaf of the $2^{\text {nd }}$ pair; arrows: glandular trichomes at two-cell stage. 15 . Developing leaves of the $5^{\text {th }}$ and $6^{\text {th }}$ pairs. 16. Developing leaf of the $6^{\text {th }}$ pair; arrow: glandular trichome at an early developmental stage. See text for description. Bar $=200 \mu \mathrm{m}(12,15), 100 \mu \mathrm{m}(13)$ and $40 \mu \mathrm{m}(14,16)$. 

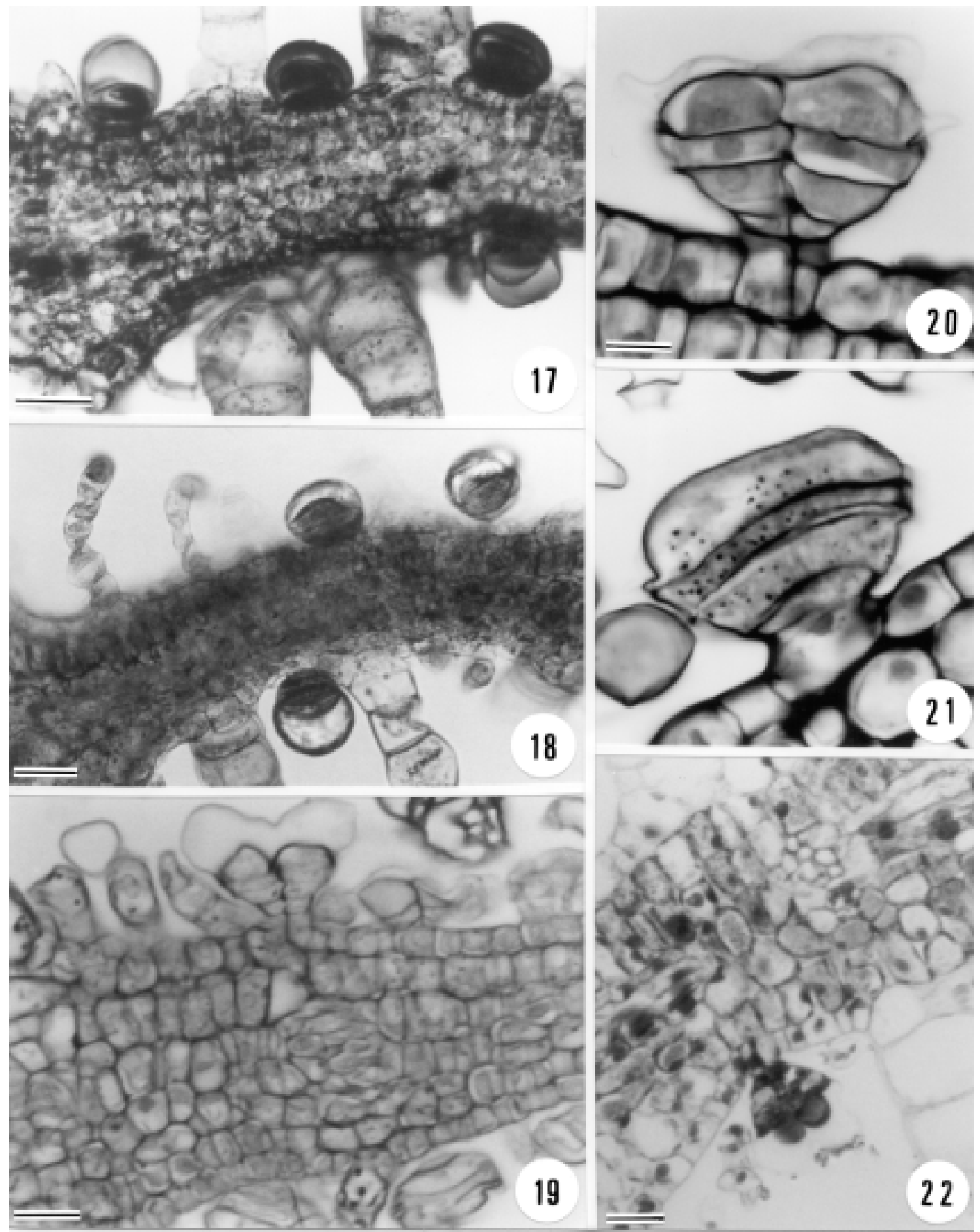

Figures 17 - 22. Stevia rebaudiana (Bert.) Bert. Mature glandular trichomes seen in transections of leaves. Histochemical tests. 17. Sudan black B. 18. Ruthenium red. 19. Alcian blue 8GS. 20, 21. PAS test. 22. Formalin - ferrous sulphate reagent. See text for description. Bar $=40 \mu \mathrm{m}(17,18), 20 \mu \mathrm{m}(19,22)$ and $10 \mu \mathrm{m}(20,21)$. 
one-cell stage. It may also be, however, at the twocell stage in a lateral view of the trichome, since such a view, also shown by figures 9 and 10 , seemed to be more frequent than the face view in the transections of the shoot apices.

On fully expanded mature leaves the glandular trichomes occur in a sparse distribution. Some histochemical aspects of mature trichomes - In the secretory sheath, a distinct staining is detected after treatment with Sudan Black B (figure 17), Ruthenium red (figure 18), Alcian blue 8GS (figure 19) and a light staining with the PAS test (figures 8, 20). The latter two dyes and the PAS test also stain the upper walls of the apical head cells subtending the trichome cavity (figures 18-20).

Secretory material collected in the trichome cavity stains intensely with Sudan black B (figure 17), and moderately with Ruthenium red (figure 18) and the PAS test. The staining resultant from the latter appears to be more expressive in materials seen along the top of the trichome apical head cells (figure 20). Secretory material of the trichome cavity also stains with Alcian blue 8GS, although in a discreet way (figure 19).

Contents of the head cells show a positive reaction to treatment with Sudan black B (figure 17). Starch grains become intensely stained when treated with the PAS test (figure 21). Contents of the head cells are also stained in material fixed in formalinferrous sulphate reagent (figure 22).

\section{Discussion}

Previous studies confirm, as reported by Carlquist (1958, 1959a, b), that the biseriate type of glandular trichome is common in the Asteraceae family, occurring in species belonging to different tribes: Anthemideae (Vermeer \& Peterson 1979a, b, Kelsey \& Shafizadeh 1980, Ascensão \& Pais 1982, Maleci \& Marchi 1983, Ascensão \& Pais 1985, Cappelletti et al. 1986, Ascensão \& Pais 1987, Jordaan \& Kruger 1992, Duke \& Paul 1993, Werker et al. 1994, Corsi \& Nencioni 1995, Ferreira \& Janick 1995), Astereae (Hellwig 1992, Castro et al. 1997), Cardueae (Schnepf 1969), Eupatorieae (Castro et al. 1997), Heliantheae (Carlquist 1958, Castro et al. 1997), Inuleae (Werker \& Fahn 1981, 1982, Castro et al. 1997), Mutisieae (Castro et al. 1997) and Vernonieae (Narayana 1979, Castro et al. 1997). In S. rebaudiana, like in other species of the genus Stevia (Castro et al.
1997), the ten-celled biseriate glandular trichome is found on both leaf surfaces.

There are, however, few ontogenetic studies on glandular trichomes in Asteraceae, and these relate to only twelve species: Adenothamnus validus, Blepharizonia plumosa, Hemizonia fitchii, $H$. minthornii, Holozonia filipes, Madia sativa (Carlquist 1958), Chrysanthemum morifolium cv. Dramatic (Vermeer \& Peterson 1979a, b), Adenocaulon bicolor Hook. (Karrfalt \& Kreitner 1980), Inula viscosa (L.) Ait. (Werker \& Fahn 1981), Artemisia crithmifolia (Ascensão \& Pais 1982), A. campestris L. ssp. maritima (Ascensão \& Pais 1985, 1987) and A. апnиa L. (Duke \& Paul 1993).

The ontogenetic development of the biseriate glandular trichome of $S$. rebaudiana occurs in an acropetal sequence (Uphof 1962), and is similar to that reported by Vermeer \& Peterson (1979a, b), Ascensão \& Pais (1982, 1985, 1987), as well as by Duke \& Paul (1993). This ontogeny also characterizes the earliest developmental phases of glandular trichomes of some species studied by Carlquist (1958). In S. rebaudiana the first division of the gland mother cell is anticlinal. For the glandular trichomes of Helichrysum aureonitens Sch. Bip. on the other hand, such a division is reported to be periclinal (Afolayan \& Meyer 1995).

In $S$. rebaudiana, fully differentiated functional glandular trichomes are already present at early stages of leaf development; in addition these glands are formed only on leaf primordia and very young leaves at various stages of differentiation. This is similar to what has been stressed for lipophilic trichomes of other species (belonging to various families, including Asteraceae), such as: Beyeria viscosa (Labill.) Miq. (Dell \& McComb 1974), Eremophila fraseri F. Meull (Dell \& McComb 1977), Inula viscosa (L.) Ait. (Werker \& Fahn 1981) and Artemisia campestris ssp. maritima (Ascensão \& Pais 1987).

Besides cutin and other possible lipidic substances existing in the cuticular membrane (this latter as defined by Holloway 1982), and revealed by Sudan black B, pectinaceous material also occurs in the secretory sheath, as indicated by the positive staining of this structure after treatment with Ruthenium red and Alcian blue 8GS. These dyes also stain the upper walls of the apical head cells subtending the trichome cavity. A discreet positive PAS test also appears in the secretory sheath. This 
test, regularly used to detect insoluble carbohydrates, can also stain pectinaceous material (Holloway 1982). These histochemical results will be related to the ultrastructure of the $S$. rebaudiana glandular trichome, and the origin of the trichome cavity in a forthcoming article. The present study suggests that the detachment of the secretory sheath from the trichome apical head cells occurs along a zone possibly containing pectin (Holloway 1982).

Histochemical characterization of the secretion products in biseriate glandular trichomes has been performed on nine species of Asteraceae: Artemisia nova Nelson (Kelsey \& Shafizadeh 1980), A. umbelliformis Lam. (Cappelletti et al. 1986), A. campestris ssp. maritima (Ascensão \& Pais 1987), A. dracunculus L. (Werker et al. 1994), A. nitida Bertol. (Corsi \& Nencioni 1995), Chrysanthemum morifolium cv. Dramatic (Vermeer \& Peterson 1979b), Inula viscosa (L.) Ait., I. crithmoides L. and I. graveolens (L.) Desf. (Werker \& Fahn 1981, 1982).

In $S$. rebaudiana, the result from Sudan black B treatment indicates that the secretory material amassed in the trichome cavity is lipophilic. It also appears to be hydrophilic, since it stains with Ruthenium red (mainly) and the PAS test. With the latter the staining seems to be more evident on the material lying on the top of the trichome apical head cells.

In biseriate glandular trichomes of the other species of Asteraceae, the results found by Werker \& Fahn (1982) for Inula crithmoides and I. graveolens, and by Werker et al. (1994) for Artemisia dracunculus, on the chemical nature of the secretory product, are similar to those of $S$. rebaudiana. Lipids were reported for Chrysanthemum morifolium cv. Dramatic (Vermeer \& Peterson 1979b), whereas lipids, as well as noncellulosic polysaccharides and proteins, were reported for Inula viscosa (Werker \& Fahn 1981, 1982).

In Artemisia campestris ssp. maritima (Ascensão \& Pais 1987) and A. nitida (Corsi \& Nencioni 1995), the secretion is an oleoresin composed of terpenoids, fatty acids, flavonoids and alkaloids in the former species, and terpenoids, steroids and sesquiterpene lactones in the latter. Presence of sesquiterpene lactones in the secretory product is mentioned for Artemisia nova (Kelsey \& Shafizadeh 1980) and A. umbelliformis (Cappelletti et al. 1986). Such compounds were also found in extracts of aerial parts of some species of Stevia, by Zdero et al. (1991) and Hernández et al. (1997).
All head cells of the mature biseriate glandular trichomes of $S$. rebaudiana contain starch grains. This is, probably, the first report of occurrence of starch in head cells of this kind of glandular trichome. In Artemisia annua L. that compound is formed only in the stalk cells (Duke \& Paul 1993). Phenolic substances were also detected in the trichome head cells.

Secretory substances, including those released by glandular trichomes, are thought to protect plants against herbivores and pathogens; also they would reduce the water loss by cuticular transpiration, as well as the leaf temperature, since the presence of such substances may result in an increase of reflectance from the leaf (Dell \& McComb 1975, 1977, Kelsey \& Shafizadeh 1980, Werker \& Fahn 1981, Cappelletti et al. 1986, Jordaan \& Kruger 1992, Duke et al. 1994, Tattini et al. 2000). Sesquiterpene lactones, already detected in aerial parts of plants of some species of the genus Stevia (Zdero et al. 1991, Hernández et al. 1997) might be among the substances composing the material produced by the glandular trichomes of $S$. rebaudiana. If present, such compounds should be of some importance in the protection of the plants. However, only the results from a detailed chemical study of the secretory material, and observations on plants growing in their natural habitat, can give the investigators a solid basis for speculations about the real function(s) of such trichomes.

Acknowledgements - Our thanks to: Dr. Lilian B.P. Zaidan (Instituto de Botânica, São Paulo City, São Paulo, Brazil) for providing seeds; Dr. Mauro Alvarez (Fundação Universidade Estadual de Maringá, Maringá City, Paraná, Brazil) for improving, in various ways, our knowledge on the stevioside; Mr. João M. Catarin (Ingá Stevia Industrial S/A, Maringá City, Paraná, Brazil) for furnishing seeds and literature on plant cultivation; Mrs. M. Ester S. Silva for photographic work.

\section{References}

AFOLAYAN, A.J. \& MEYER, J.J.M. 1995. Morphology and ultrastructure of secreting and nonsecreting foliar trichomes of Helichrysum aureonitens (Asteraceae). International Journal of Plant Sciences 156:481-487.

ASCENSÃO, L. \& PAIS, M.S.S. 1982. Secretory trichomes from Artemisia crithmifolia: some ultrastructural aspects. Bulletin de la Société Botanique de France 129, Actualités Botaniques 1:83-87.

ASCENSÃO, L. \& PAIS, M.S.S. 1985. Différenciation et processus sécréteur des trichomes d'A. campestris ssp. maritima (Compositae). Annales des Sciences Naturelles, Botanique 13e série 7:149-171. 
ASCENSÃO, L. \& PAIS, M.S.S. 1987. Glandular trichomes of Artemisia campestris (ssp. maritima): ontogeny and histochemistry of the secretory product. Botanical Gazette 148:221-227.

CAPPELlETti, E.M., CANIATO, R. \& APPENDINO, G. 1986. Localization of the cytotoxic hydroperoxyeudesmanolides in Artemisia umbelliformis. Biochemical Systematics and Ecology 14:183-190.

CARLQUIST, S. 1958. Structure and ontogeny of glandular trichomes of Madinae (Compositae). American Journal of Botany 45:675-682.

CARLQUIST, S. 1959a. The leaf of Calycadenia and its glandular appendages. American Journal of Botany 46:7080 .

CARLQUIST, S. 1959b. Glandular structures of Holocarpha and their ontogeny. American Journal of Botany 46:300308

CASTRO, M.M., LEITÃO FILHO, H.F. \& MONTEIRO, W.R. 1997. Utilização de estruturas secretoras na identificação dos gêneros de Asteraceae de uma vegetação de cerrado. Revista Brasileira de Botânica 20:163-174.

CLARK, G. 1981a. Introduction. In Staining procedures (G. Clark, ed.). Williams \& Wilkins, Baltimore, p.1-26.

CLARK, G. 1981b. Miscellaneous methods . In Staining procedures (G. Clark, ed.). Williams \& Wilkins, Baltimore, p. 171-215.

CORSI, G. \& NENCIONI, S. 1995. Secretory structures in Artemisia nitida Bertol. (Asteraceae). Israel Journal of Plant Sciences 43:359-365.

DELL, B. \& McCOMB, A.J. 1974. Resin production and glandular hairs in Beyeria viscosa (Labill.) Miq. (Euphorbiaceae). Australian Journal of Botany 22:195210.

DELL, B. \& McCOMB, A.J. 1975. Glandular hairs, resin production, and habitat of Newcastelia viscida E. Pritzel (Dicrastylidaceae). Australian Journal of Botany 23:373390.

DELL, B. \& McCOMB, A.J. 1977. Glandular hair formation and resin secretion in Eremophila fraseri $\mathrm{F}$. Meull (Myoporaceae). Protoplasma 92:71-86.

DUFFEY, S.S. 1986. Plant glandular trichomes: their partial role in defence against insects. In Insects and the plant surface (B.E. Juniper \& T.E. Southwood, eds.). Arnold, London, p.151-172.

DUKE, S.O. 1994. Glandular trichomes - a focal point of chemical and structural interactions. International Journal of Plant Sciences 155:617-620.

DUKE, S.O. \& PAUL, R.N. 1993. Development and fine structure of the glandular trichomes of Artemisia annua L. International Journal of Plant Sciences 154:107-118.

DUKE, M.V., PAUL, R.N., ELSOHLY, H.N., STURTZ, G. \& DUKE, S.O. 1994. Localization of artemisinin and artemisitene in foliar tissues of glanded and glandless biotypes of Artemisia annua L. International Journal of Plant Sciences 155:365-372.

FAHN, A. 1979. Secretory tissues in plants. Academic Press, London.

FELIPPE, G.M. 1977. Stevia rebaudiana Bert.: uma revisão. Ciência e Cultura 29:1240-1248.

FERREIRA, J.F.S. \& JANICK, J. 1995. Floral morphology of Artemisia annua with special reference to trichomes. International Journal of Plant Sciences 156:807-815.
HANDRO, W. \& FERREIRA, C.M. 1989. Stevia rebaudiana (Bert.) Bertoni: production of natural sweeteners. In Biotechnology in agriculture and forestry (Y.P.S. Bajaj, ed.). Springer-Verlag, Berlin, p.468-487.

HELLWIG, F.H. 1992. Untersuchungen zur Behaarung ausgewählter Astereae (Compositae). Flora 186:425-444.

HERNÁNDEZ, Z.N.J., HERNÁNDEZ, L.R., CATALÁN, C.A.N., GEDRIS, T.E. \& HERZ, W. 1997. Guaianolides and germacradienolides from Stevia sanguinea. Phytochemistry 46:721-727.

HOLLOWAY, P.J. 1982. Structure and histochemistry of plant cuticular membranes: an overview. In The plant cuticle (D.F. Cutler, K.L. Alvin \& C.E. Price, eds.). Academic Press, London, p.1-32.

JENSEN, W.A. 1962. Botanical histochemistry: principles and practice. W.R. Freeman, San Francisco.

JOHANSEN, D.A. 1940. Plant microtechnique. McGrawHill, New York.

JORDAAN, A. \& KRUGER, H. 1992. Leaf surface and anatomy of two xerophytic plants from southern Africa. South African Journal of Botany 58:133-138.

KARRFALT, E.E. \& KREITNER, G.L. 1980. The development of the glandular trichomes of Adenocaulon bicolor. Canadian Journal of Botany 58:61-67.

KELSEY, R.G. 1984. Glandular trichomes: a helpful taxonomic character for Artemisia nova (Black Sagebrush). Journal of Range Management 37:370-372.

KELSEY, R.G. \& SHAFIZADEH, F. 1980. Glandular trichomes and sesquiterpene lactones of Artemisia nova (Asteraceae). Biochemical Systematics and Ecology 8:371-377.

KELSEY, R.G., REYNOLDS, G.W. \& RODRIGUEZ, E. 1984. The chemistry of biologically active constituents secreted and stored in plant glandular trichomes. In Biology and chemistry of plant trichomes (E. Rodriguez, P.L. Healey \& I. Mehta, eds.). Plenum Press, New York, p.187-241.

KINGHORN, A.D. \& SOEJARTO, D.D. 1991. Stevioside. In Alternative sweeteners, (L. O’Brien Nabors \& R.C. Gelardi, eds.). Marcel Dekker, New York, v.2, p.157171.

LERSTEN, N.R. \& CURTIS, J.D. 1988. Secretory reservoirs (ducts) of two kinds in giant ragweed (Ambrosia trifida; Asteraceae). American Journal of Botany 75:1313-1323.

LEVIN, D.A. 1973. The role of trichomes in plant defense. The Quarterly Review of Biology 48: 3-15.

MALECI, L.B. \& MARCHI, A.B. 1983. "Artemisia vulgaris" L. ed "A. verlotiorum" Lamotte: studio di alcuni caratteri morfo-anatomici distintivi delle due specie. Webbia 37:185-196.

MELIS, M.S. 1995. Chronic administration of aqueous extract of Stevia rebaudiana in rats: renal effects. Journal of Ethnopharmacology 47:129-134.

MONTEIRO, R. 1982. Estudos taxonômicos em Stevia série Multiaristatae no Brasil. Revista Brasileira de Botânica 5:5-15.

NARAYANA, B.M. 1979. Taxonomic value of trichomes in Vernonia Schreb. (Asteraceae). Proceedings of the Indian Academy of Sciences 88B, part II:347-357.

RIDING, R.T. \& GIFFORD, E.M., JR. 1973. Histochemical changes occurring at the seedling shoot apex of Pinus radiata. Canadian Journal do Botany 51:501-512. 
SCHNEIDER, H. 1981. Plant anatomy and general botany. In Staining procedures (G. Clark, ed.). Williams \& Wilkins, Baltimore, p.315-333.

SCHNEPF, E. 1969. Über den Feinbau von Öldrüsen. I. Die Drüsenhaare von Arctium lappa. Protoplasma 67:185-194.

SPRING, O. 1991. Trichome microsampling of sesquiterpene lactones for the use of systematic studies. In Modern phytochemical methods (N.H. Fischer, M.B. Isman \& H.A. Stafford, eds.). Plenum Press, New York, p.319-345.

TATTINI, M., GRAVANO, E., PINELLI, P., MULINACCI, N. \& ROMANI, A. 2000. Flavonoids accumulate in leaves and glandular trichomes of Phillyrea latifolia exposed to excess solar radiation. New Phytologist 148:69-77.

TOSKULKAO, C., DEECHAKAWAN, W., LEARDKAMOLKARN, V. \& GLINSUKON, T. 1994. The low calorie natural sweetener stevioside: nephrotoxicity and its relationship to urinary enzyme excretion in the rat. Phytotherapy Research 8:281-286.

UPHOF, J.C.TH. 1962. Plant hairs. In Encyclopedia of plant anatomy (W. Zimmermann \& P.G. Ozenda, eds.). Borntraeger, Berlin, v.4, p.1-206.

VÁLIO, I.F.M. \& ROCHA, R.F. 1977. Effect of photoperiod and growth regulator on growth and flowering of Stevia rebaudiana Bertoni. Japanese Journal of Crop Science 46:243-248.

VERMEER, J. \& PETERSON, R.L. 1979a. Glandular trichomes on the inflorescence of Chrysanthemum morifolium cv. Dramatic (Compositae). I. Development and morphology. Canadian Journal of Botany 57:705-713.
VERMEER, J. \& PETERSON, R.L. 1979b. Glandular trichomes on the inflorescence of Chrysanthemum morifolium cv. Dramatic (Compositae). I. Ultrastructure and histochemistry. Canadian Journal of Botany 57:714729.

WAGNER, G.J. 1991. Secreting glandular trichomes: more than just hairs. Plant Physiology 96: 675-679.

WERKER, E. \& FAHN, A. 1981. Secretory hairs of Inula viscosa (L.) Ait. - development, ultrastructure, and secretion. Botanical Gazette 142:461-476.

WERKER, E. \& FAHN, A. 1982. Inula hairs - structure, ultrastructure and secretion. In Aromatic plants: basic and applied aspects (N. Margaris, A. Koedam \& D. Vokou, eds.). Martinus Nijhoff Publishers, The Hague, p.25-37.

WERKER, E., PUTIEVSKY, E., RAVID, U., DUDAI, N. \& KATZIR, I. 1994. Glandular hairs, secretory cavities, and the essential oil in leaves of Tarragon (Artemisia dracunculus L.). Journal of Herbs, Spices \& Medicinal Plants 2:19-32.

ZAIDAN, L.B.P., DIETRICH, S.M.C. \& FELIPPE, G.M. 1980. Effect of photoperiod on flowering and stevioside content in plants of Stevia rebaudiana Bertoni. Japanese Journal of Crop Science 49:569-574.

ZDERO, C., BOHLMANN, F. \& NIEMEYER, H.M. 1991. Guaianolides and other constituents from Stevia species. Phytochemistry 30:693-695. 
